\title{
Reservasjonsretten er nødvendig
}

\author{
Mange leger føler seg sviktet når Helse- og omsorgsdepartementet nå fjerner muligheten for fastleger \\ til å reservere seg mot å henvise gravide til provosert abort.
}

Publisert først på nett 29.2. 2012

Det har lenge vært en innarbeidet og akseptert praksis at etisk bevisste fastleger kan reservere seg mot å henvise til provosert abort (1). 31.10. 2011 fjernet Helse- og omsorgsdepartementet denne muligheten, og vedtaket er bifalt av Legeforeningen (2). Rådet for legeetikk kritiserte innskjerpingen, og rådets leder uttalte til Aftenposten at dette «må bety yrkesforbud som fastlege for leger som ikke er villige til å gå på akkord med et visst livssyn» (3).

Mange leger føler seg nå sviktet av sin egen fagforening. Legeforeningen begrunner støtten til departementet med at man ikke ønsker «en situasjon der pasienter frykter å bli avvist i sitt møte med helsetjenesten» (4). Dette lyder jo prisverdig, men reservasjonsretten gjaldt aldri behandling eller forebygging av sykdom, men ulike former for etisk omstridt helsehjelp som ligger utenfor den tradisjonelle legerollen.

\section{«Som lege har man ansvar for liv, også for fosterets liv»»}

Det er derfor trist og urovekkende når Legeforeningen, i strid med mange medlemmers ønsker, Rådet for legeetikk og Europarådets resolusjon (som er rådgivende for medlemslandene, også Norge) (5), velger å støtte Helse- og omsorgsdepartementet i denne saken. Selvfølgelig må reservasjonsretten ha klare rammer, og heller ikke kan alle ønsker om reservasjon støttes (6). Mange har moralske reservasjoner, men mindre er sagt om den personlige begrunnelsen.

\section{Gradert menneskeverd}

Abort er «avbrudd» av et påbegynt liv, men et liv som av lovverk og samfunn generelt ikke anses som fullverdig, og som derfor kan ofres.

Gradert menneskeverd kan illustreres slik: En person har en hjemmeboende, aldrende svigermor med begynnende demens, men som nekter å bli flyttet til sykehjem. Pleieoppgavene medfører at personen må gå i $40 \%$ stilling, så økonomien og karrieren lider skade. Samfunnet anser svigermors liv som fullverdig og vil ikke tillate at svigermoren tas av dage. Fostres liv, derimot, graderes av abortloven. Kriteriene for å kunne utføre abort er vanskeligere å oppfylt når graviditetens lengde øker fra 12 opp mot 18 uker. Etter 18 uker er abort ikke tillatt «med mindre det er særlig tungtveiende grunner for det». Hvis graviditeten har gått så langt at fosteret kan være levedyktig (i dag ca. 23 uker), kan ikke abort innvilges på noe grunnlag (7).

Som lege har man ansvar for liv, også for fosterets liv. Uten gradert menneskeverd kan man ikke henvise til abort. Har legen et menneskesyn som innebærer at fosteret har fullt menneskeverd, kan man ikke henvise til abort, like lite som man med samvittigheten i behold kan skrive ut kjøreseddel til svaksynte eller unnlate å rapportere barnemishandling.

Fosteret er så likt et spedbarn at gynekologer som utfører ultralydundersøkelser, ikke skal vise videoen til abortsøkende. En film om et abortinngrep ville likne en skrekkfilm, der forsvarsløse spedbarn er ofrene. De leger som opplever abort slik, kan av samvittighetshensyn ikke henvise til «svangerskapsavbrudd». Klientens, samfunnets og lovens krav blir sekundære. Hippokrates ville vært enig (8).

Noen hevder at fosteret er en celleklump i kvinnens kropp, og påberoper seg retten til å bestemme over min egen kropp. Følger man logikken her, sier man da at kvinnen da har to hjerner, to tunger, og to sett med genitalia. Man kunne like gjerne hevdet at kvinnen er en del av fosterets kropp.

\section{Vansker for mor}

Vanskene for mor skal ingen underslå. En undersøkelse der kvinner ble spurt om årsaken til at de fikk utført provosert abort, svarte tre firedeler at det å ha et barn ville skape vansker med arbeid, skolegang eller andre forpliktelser, rundt to tredeler sa at de ikke hadde råd til å ha et barn, og rundt halvparten sa at de ikke ønsket å være enslig mor eller de hadde et vanskelig forhold til sine nærmeste (9). Mindre enn $2 \%$ av alle aborter utføres pga, voldtekt, incest eller fare for mors liv.

Noen vil påstå at dersom en lege nekter å henvise til provosert abort, så kan vedkommende ikke bli allmennlege. Men landet har foreløpig turnustjeneste med allmennpraksis som kan innebære abortsøknader. Helse- og omsorgsdepartementet er uklare på om også turnusleger må utføre alle fastlegeoppgaver.
Hva skjer med profesjonsetikken om de kritiske røstene fjernes? Uten reservasjonsrett blir jobbsituasjonen for mange uholdbar. Mange uønsket gravide er utvilsomt i en svært vanskelig situasjon, men det forsvarer ikke å pålegge leger å måtte henvise uskyldige liv til døden.

Jeg vil bruke mine evner for det beste for mine pasienter i samsvar med min dyktighet og min dømmekraft og aldri volde noe skade. Jeg vil ikke gi dødelig gift til noen som ber om det, heller ikke gi råd til hvordan de kan avslutte sitt liv (8).

\section{Bjørn A. Helland-Hansen}

hellandhansen@me.com

Levanger

Bjørn A. Helland-Hansen (f. 1971) var i siviltjenesten kommunelege $f ø r$ han ble spesialist i øyesykdommer. I 2011 var han overlege på sykehuset i Molde, men jobber nå på sykehuset i Lillehammer. Han har et bredt sosialt engasjement, også internasjonalt, bl.a. som øyelege i Sentral-Asia.

Forfatter har fylt ut ICMJE-skjemaet og oppgir ingen interessekonflikter.

\section{Litteratur}

1. Markestad T, Hytten K. Hvor går grensen for reservasjonsretten? Tidsskr Nor Legeforen 2010; 130: $1844-5$

2. Sønderland K, Valle AL. Rundskriv. Om reservasjon for leger $\mathrm{i}$ den kommunale helse- og omsorgstjenesten. Oslo: Helse- og omsorgsdepartementet, 2011

3. Dommerud T. Leger kan få yrkesforbud. Aftenposten 4.11.2011. www.aftenposten.no/helse/ Leger-kan-f-yrkesforbud-6687797.html (4.1.2012).

. Bråten KE. Ingen generell reservasjonsrett. Tidsskr Nor Legeforen 2011; 131: 1112

5. Parliamentary Assembly. Council of Europe. Resolution 1763 (2010). www.assembly.coe.int/ main.asp?Link=/documents/adoptedtext/ta10/ eres1763.htm (4.1.2012)

6. Magelssen M, Fredheim OM. Når bør leger ha reservasjonsrett? Tidsskr Nor Legeforen 2011; 131: $2518-9$

7. Wikipedia. Abort. http://no.wikipedia.org/wiki/ Abort (4.1.2012).

8. Wikipedia. Den hippokratiske ed. http://no.wikipedia.org/wiki/ Den_hippokratiske_ed (4.1.2012)

9. Torres A, Forrest JD. Why do women have abortions? Fam Plann Perspect 1988; 20: 169-76.

Mottatt 9.1. 2012 og godkjent 26.1. 2012. Medisinsk redaktør Petter Gjersvik. 